www.jmscr.igmpublication.org Impact Factor 5.244

Index Copernicus Value: 83.27 ISSN (e)-2347-176x ISSN (p) 2455-0450 crossref DOI: _https://dx.doi.org/10.18535/jmscr/v4i11.08

\author{
Journal Of Medical Science And Clinical Research \\ IGM Publication \\ An Official Publication of IGM Publication
}

\title{
A Report on Outbreak investigation of Dengue in Bihar in 2015
}

\author{
Authors \\ Ragini Mishra $^{1} *$, Prashant Kumar ${ }^{2}$ \\ ${ }^{1}$ State Epidemiologist, State Health Society, Bihar \\ ${ }^{2}$ District Epidemiologist, District Health Society, Patna
}

\begin{abstract}
Dengue outbreak is repeatedly being reported in Bihar. In 2015, many districts were affected with the disease. Outbreak investigation was carried in Patna, Bhojpur, Aurangabad and Gaya district Bihar to determine the causes of outbreak. Epidemiological, Entomological and Socio-environmental survey was done to know the reasons of outbreak and to suggest remedial actions. Analysis of data collected at the State level was also done. Disease afflicted almost all age groups but the incidence was more in 21-30 age group. Males were more affected than females. Vector and larval surveillance in the affected areas were positive. Per Man Hour density of Aedes aegypti was also above the critical limit of transmission. High House and Briteau Index in all the four districts posed significant risk of outbreaks. Around $70 \%$ of the population was aware about the term Dengue; however knowledge about various aspects were lacking. Around $80 \%$ of the population stored water at home. Only $10 \%$ of the population cleaned/changed the water stored in domestic or peri-domestic containers. Majority of the cases were reported in monsoon and post-monsoon season. Community support and participation is also crucial for the prevention of future outbreaks and improving the health and well being of population in the districts.

Keywords: Dengue, Outbreak, Epidemiological, Entomological.
\end{abstract}

\section{Introduction}

Dengue fever (DF) is a mosquito-borne viral infection ${ }^{[1]}$. Dengue fever is an acute febrile illness of 2-7 days duration with two or more of the following: headache, retro-orbital pain, myalgia, arthralgia, rash, haemorrhagic manifestations, leucopoenia ${ }^{[2,3]}$ and with one or more of the following:

a) Supportive serology (reciprocal haemagglutination inhibition antibody titer, comparable IgG EIA titre or positive IgM antibody test in late acute or convalescentphase serum specimen). b) Epidemiologically linked with a confirmed case of dengue fever (occurrence at same location and time as other confirmed cases of dengue fever).

Aedes aegypti, the main vector species of dengue fever/dengue haemorrhagic fever (DHF) is commonly found in urban and peri-urban areas which can be attributed to the availability of breeding sites such as water storage containers due to poor management of water and limited supply of drinking water, non degradable tyres, long lasting plastic containers and ineffective community participation in eliminating the breeding places ${ }^{[4,5]}$. Dengue viruses (DV) belong 
to the family Flaviviridae, having four serotypes referred to as DV-1, DV-2, DV-3, and DV-4 ${ }^{[6]}$. Dengue infection though endemic in India for over two centuries as a benign and self-limited disease has changed its course in recent years manifesting in the severe form as DHF and with increasing frequency of outbreaks ${ }^{[7]}$. Several outbreaks occurred in India including Bihar ${ }^{[8-13]}$. Specific Objectives of the outbreak investigation was to review and assess the situation of Dengue fever outbreak in 4 districts of Bihar, to determine the causes of current outbreak, to conduct an epidemiological and also entomological survey in some of the affected areas of Patna, Bhojpur, Aurangabad and Gaya, to assess the environmental and sociological factors contributing to the abundance of Dengue vector, to assess the current situation by state wise analysis of Dengue outbreak and to recommend remedial measures to overcome the current outbreak and prevent occurrence of outbreaks in future.

\section{Methodology}

Discussion with the District authorities and medical and paramedical staff to know the background information of the affected areas, genesis of outbreak, investigations carried out so far and control measures undertaken; Discussion with the physicians who treated the cases about the clinical presentation of cases, results of laboratory investigations and outcome of cases; Interview and clinical examination of some of the cases; Visit to affected areas, Rapid fever survey by house to house visit and collection of sera samples from suspected cases for Dengue IgM ELISA test, Entomological investigations based on adult \& larval survey was done to understand the vector species prevalent in the area; Examination of water storage practices and Environmental investigation, knowledge, attitude $\&$ practices of the community were also analyzed as per pre-planned questionnaire.

Patna District Profile: Patna district occupies an area of 3,202 square kilometers, population, as per 2011 is $5,838,465$, while its density is $1,800 / \mathrm{km} 2$, urban population is $43.7 \%$. Literacy rate is 70.68 $\%$.It has 20 blocks \& 6 sub divisions. Yearly average maximum \& minimum temperature is $31.53 \& 19.65$ degree Celsius. Major crops grown include Paddy, Maize, Pulses and Wheat \& Oil seeds. Roughly one third of the area sown is under rice (paddy). Cash crops such as vegetables and water-melons are also grown in diara belt. Major industries include leather, handicrafts, and agro processing.

Bhojpur District Profile: Bhojpur district occupies an area of 2,395 square kilometers. It is located at a longitude of $83^{\circ} 45^{\prime}$ to $84^{\circ} 45^{\prime}$ East and the latitude is $25^{\circ} 10^{\prime}$ to $25^{\circ} 40^{\prime}$ North and is situated at a height of 193 meters above sea level. According to the 2011 census Bhojpur district, Bihar has a population of 2,720,155. The district has a population density of 1,136 inhabitants per square kilometer. Its population growth rate over the decade 2001-2011 was $21.27 \%$.It has literacy rate of $72.79 \%$. It has 14 blocks \& 3 sub divisions. Agricultural crops grown are Paddy, Wheat, Maize, Bengal Gram, Grain

Aurangabad District Profile: Aurangabad district occupies an area of 3,389 square kilometers. It has 11 blocks and 2 sub divisions. According to the 2011 census Aurangabad district, Bihar has a population of 2,511,243. The district has a population density of 760 inhabitants per square kilometer. Its population growth rate over the decade 2001-2011 was $24.75 \%$.It has literacy rate of $72.77 \%$. This district lies between $24.750 \mathrm{~N}$ and 84.370 E. The climate of this region is Tropical. During the summer days temperature rises up to $40{ }^{\circ} \mathrm{C}$ to $50{ }^{\circ} \mathrm{C}$, whereas during the winter temperature falls almost near $5{ }^{\circ} \mathrm{C}$. Rainfall in this region is average near 50 centimeter to 75 centimeter. The soil of this district is highly suitable for the agriculture of paddy, wheat and sugar-cane. The irrigation-planning has made the land of this district most fertile and suitable for agriculture.

Gaya District Profile: Gaya district occupies an area of 4,976 square kilometers. Total area is $4,976 \mathrm{~km}^{2}$. It has 24 blocks \& 4 sub divisions. 
According to the 2011 census Gaya district has a population of $4,379,383$. The district has a population density of 880 inhabitants per square kilometer. Its population growth rate over the decade $2001-2011$ was $26.08 \%$ \& literacy rate is $66.35 \%$.Longitudinal extension is $84.40-85.50$ east and latitudinal extension is 24.50-25.100 towards north. Principal crops grown are Paddy, wheat, lentils and potato.

\section{Results and Discussion}

Figure 1: Time wise distribution of Dengue cases in Bihar

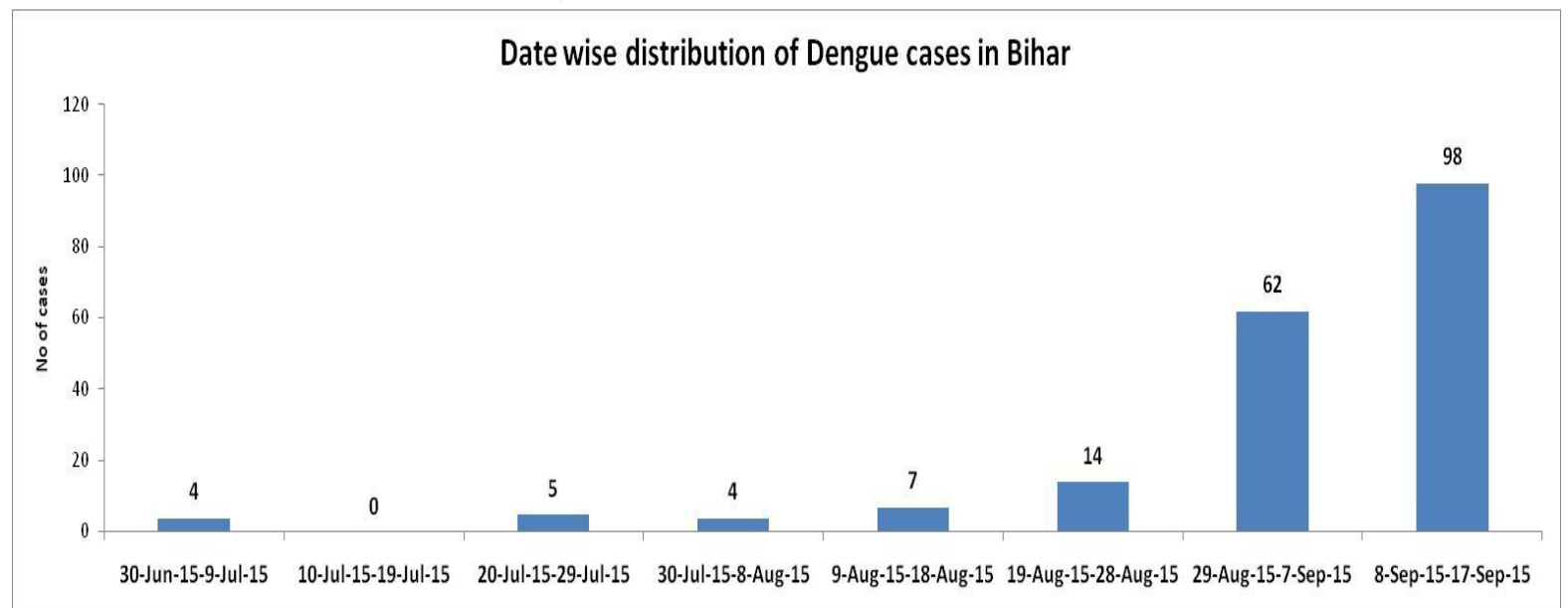

Figure 2: Time wise distribution of Dengue cases in Patna, Bhojpur, Aurangabad \& Gaya

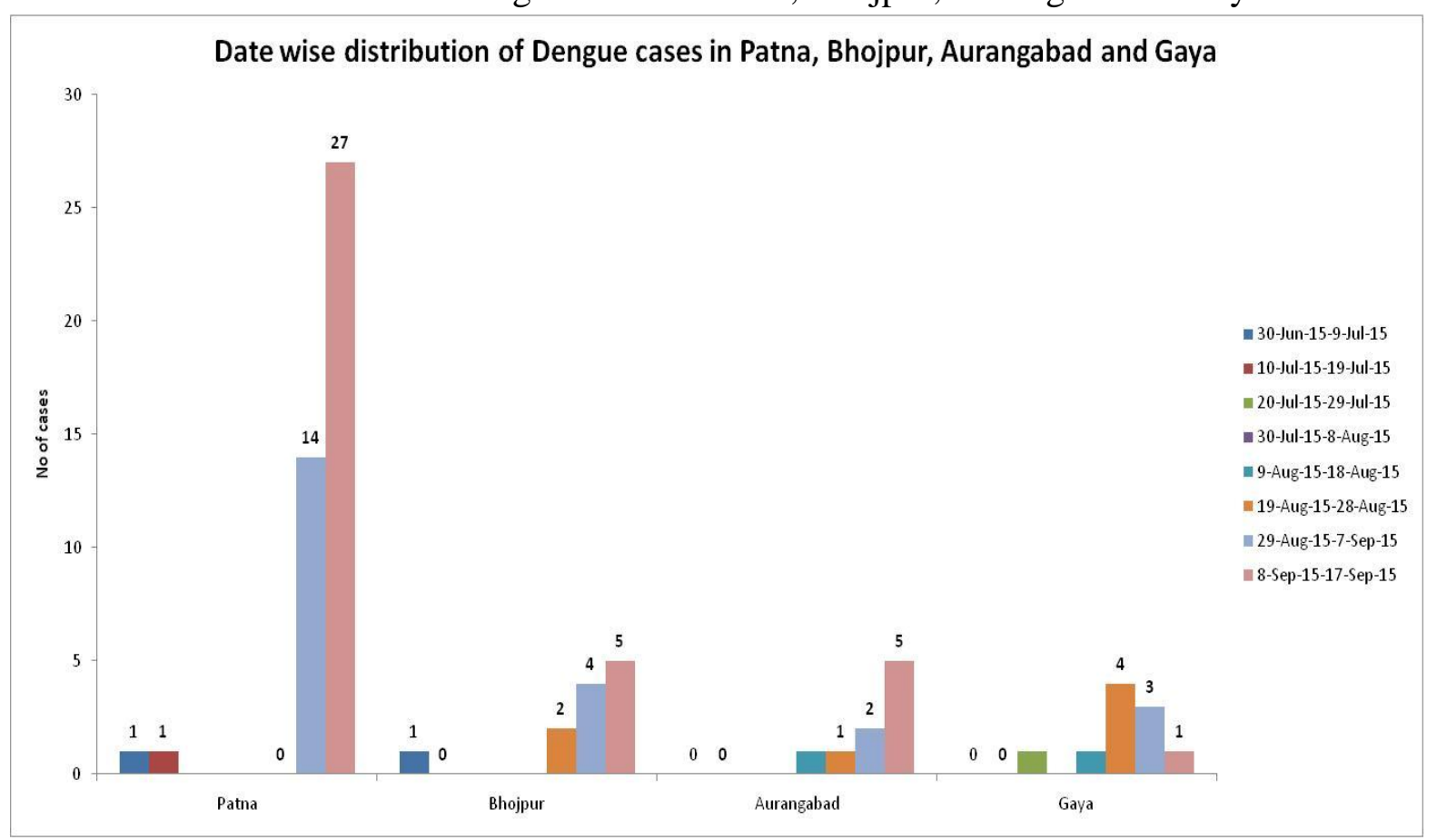


Table 1: Person wise distribution of Dengue cases in Bihar

Age wise distribution
\begin{tabular}{|l|l|l|}
\hline Age Group & Frequency & Percentage $(\%)$ \\
\hline $0-10$ & 11 & 6 \\
\hline $11-20$ & 57 & 32 \\
\hline $21-30$ & 66 & 36 \\
\hline $31-40$ & 27 & 15 \\
\hline $41-50$ & 9 & 5 \\
\hline $51+$ & 11 & 6 \\
\hline Total & 181 & 100 \\
\hline Data NA & 13 & \\
\hline Sex wise distribution & \multicolumn{2}{|}{} \\
\hline Sex & Frequency & Percentage $(\%)$ \\
\hline Male & 158 & 81 \\
\hline Female & 36 & 19 \\
\hline Total & 194 & 100 \\
\hline
\end{tabular}

Table 2: Person wise distribution of Dengue cases in Patna, Bhojpur, Aurangabad \& Gaya

\begin{tabular}{|l|l|l|l|l|}
\hline \multirow{2}{*}{ Age group } & \multicolumn{2}{|l|}{} & \multicolumn{2}{l|}{ District } \\
\cline { 2 - 5 } & $\begin{array}{l}\text { Patna } \\
\text { Frequency/Perc } \\
\text { entage }(\%)\end{array}$ & $\begin{array}{l}\text { Bhojpur } \\
\text { Frequency/Percen } \\
\text { tage }(\%)\end{array}$ & $\begin{array}{l}\text { Aurangabad } \\
\text { Frequency/Percen } \\
\text { tage }(\%)\end{array}$ & $\begin{array}{l}\text { Gaya } \\
\text { Frequency/Percen } \\
\text { tage }(\%)\end{array}$ \\
\hline $0-10$ & $3(7)$ & $0(0)$ & $2(22)$ & $2(23)$ \\
\hline $11-20$ & $11(27)$ & $4(40)$ & $3(33)$ & $0(0)$ \\
\hline $21-30$ & $19(46)$ & $3(30)$ & $3(33)$ & $3(33)$ \\
\hline $31-40$ & $3(7)$ & $3(30)$ & $0(0)$ & $2(22)$ \\
\hline $41-50$ & $1(3)$ & $0(0)$ & $1(12)$ & $1(11)$ \\
\hline $51+$ & $4(10)$ & $0(0)$ & $0(0)$ & $1(11)$ \\
\hline Total & 41 & 10 & 9 & 9 \\
\hline Data NA & 2 & 2 & 1 & 1 \\
\hline Sex & Patna & Bhojpur & $\begin{array}{l}\text { Aurangabad } \\
\text { Frequency/Percen } \\
\text { tage }(\%)\end{array}$ & $\begin{array}{l}\text { Frequency/Percen } \\
\text { tage }(\%)\end{array}$ \\
\hline Male & $\begin{array}{l}\text { Frequency/Perc } \\
\text { entage }(\%)\end{array}$ & $\begin{array}{l}\text { Frequency/Percen } \\
\text { tage }(\%)\end{array}$ & $9(90)$ & $6(60)$ \\
\hline Female & $36(84)$ & $11(92)$ & $1(10)$ & $4(40)$ \\
\hline Total & $7(16)$ & $1(8)$ & 10 & 10 \\
\hline
\end{tabular}


Figure 3: Place wise distribution of dengue cases in Bihar including Patna, Bhojpur, Aurangabad \& Gaya

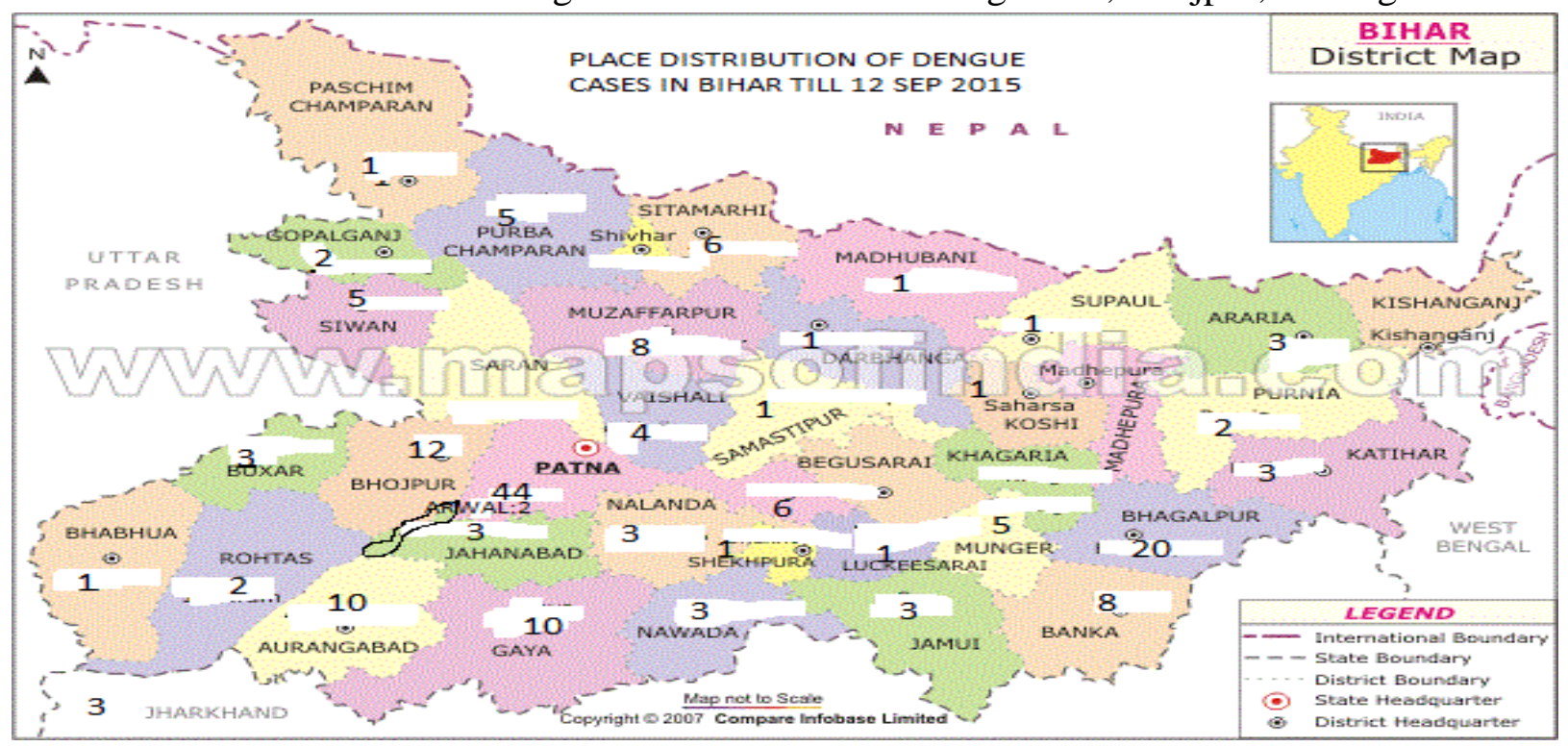

Table 3: Clinical presentation of dengue fever

\begin{tabular}{|l|l|}
\hline \multicolumn{2}{|l|}{$\begin{array}{l}\text { Clinical presentation of fever cases, Bihar Based on interview with patients \& as per reports of clinicians } \\
\text { (n=50). Includes combined figures from Patna, Bhojpur, Aurangabad \& Gaya }\end{array}$} \\
\hline Clinical symptom & Affected $(\%)$ \\
\hline Fever & $50(100)$ \\
\hline Headache & $50(100)$ \\
\hline Myalgia & $26(52)$ \\
\hline Retro-orbital pain & $45(90)$ \\
\hline Nausea/vomiting & $48(96)$ \\
\hline Diarrhoea & $5(10)$ \\
\hline Pain abdomen & $5(10)$ \\
\hline Petechiae/rash & $0(0)$ \\
\hline Dark coloured stool (malaena) & $0(0)$ \\
\hline Bleeding gums & $(0)$ \\
\hline
\end{tabular}

Table 4: Serological status of dengue in Bihar

\begin{tabular}{|l|l|l|}
\hline Test & Number & Percentage (\%) \\
\hline Rapid NS1, IgM, IgG \& PC +ve & 44 & 23 \\
\hline IgM ELISA +ve & 148 & 76 \\
\hline NS1 ELISA +ve & 2 & 1 \\
\hline Total & 194 & \\
\hline
\end{tabular}

Table 5: Institution wise status of dengue in Bihar

\begin{tabular}{|l|l|}
\hline ANMCH, Gaya & 9 \\
\hline JLNMCH, Bhagalpur & 32 \\
\hline SKMCH, Muzaffarpur & 10 \\
\hline PMCH, Patna & 116 \\
\hline NMCH, Patna & 6 \\
\hline Sadar Hospital & 7 \\
\hline RMRI & 1 \\
\hline Private Labs & 6 \\
\hline Cross-notified from other states & 7 \\
\hline Total & 194 \\
\hline
\end{tabular}


Total 194 cases of Dengue were reported in Bihar from 30 June 2015 till 17 Sep 2015.The index case was reported on 30 June 2015 from Patna district. Incidence of dengue cases was more in Patna (44)> Bhagalpur(20)>Bhojpur (12)> Aurangabad and Gaya (10 cases each).The disease afflicted almost all the age group but the incidence was more in the age group 21-30 (36\%)>11-20 $(32 \%)>31-40(15 \%) .{ }^{[15]}$ Males $(81 \%)$ were more affected than females (19\%) ${ }^{[16]}$. The most common clinical features shown by Dengue patients were fever $(100 \%)$, headache $(100 \%)$ and nausea/vomiting (48\%). No patients surveyed suffered from rash. Out of the total 194 cases (7 cases cross notified by other States), $76 \%$ of the patients were IgM ELISA positive, $1 \%$ were NS1 ELISA positive and $23 \%$ were rapid NS1/IgM/ IgG positive (suspected dengue).Lots of construction activities were seen in the villages surveyed in Bhojpur, Aurangabad and Gaya that might be in transitional stage from rural to semiurban. Multistoried buildings were seen in affected areas of Patna district that were surveyed for checking the larval breeding areas. During rapid fever survey in affected areas, 2 blood samples each were collected from Aurangabad and Gaya districts from symptomatic patients. Both blood samples from Aurangabad were confirmed for dengue while 1 blood sample out of two was confirmed for dengue in Gaya by Microbiology Department, PMCH, Patna. This emphasizes the need for rapid fever survey by the health workers for early case detection and its referral as per need. History of travel outside the locality was significant during the field visit. On the basis of overall analysis of state wise data, approximately, $15 \%$ of the total dengue cases reported showed migration history to places like Delhi, Rajasthan, Chennai, Shimla and Gurgaon. Majority had returned with dengue symptoms in the State. However, during survey in affected areas, local transmission of the disease was observed. The general weather condition during the last one month before the outbreak was hot and humid followed by spells of rain. ${ }^{[16]}$ The disease incidence increased in monsoon and post monsoon season A large population in affected areas of the four districts did not receive continuous supply of piped water. As a result of the intermittent supply, water storage practices mainly in big cement and plastic tanks were common.

Entomological Observations \& Results: is based on adult mosquitoes collected by Suction tube method \& aspirator torch in indoors in Human Dwellings during day hours. Resting collection was done for aedes. Larval sampling was done using various indices like House, Container and Briteau index. All the domestic and peri-domestic premises were searched. Containers such as tyres, plastic materials, earthen pots, tin items, cement tanks, coolers \& other miscellaneous items were thoroughly searched for mosquito breeding sites. 
Table 6: Aedine Larval and adult per man per hour density survey results

\begin{tabular}{|c|c|c|c|c|c|c|c|c|c|}
\hline \multirow{3}{*}{ SNO } & \multirow{3}{*}{ Indexes } & \multirow[b]{2}{*}{ Patna } & \multirow[b]{2}{*}{ Bhojpur } & \multirow[b]{2}{*}{ Aurangabad } & \multirow[b]{2}{*}{ Gaya } & \multicolumn{4}{|c|}{ Per Man Hour Density of Aedes } \\
\hline & & & & & & Patna & Bhojpur & Aurangabad & Gaya \\
\hline & & Results & Results & Results & Results & \multirow{8}{*}{4.1} & \multirow{8}{*}{1} & \multirow{8}{*}{1.8} & \multirow{8}{*}{1.5} \\
\hline 1 & Houses surveyed & 20 & 20 & 20 & 20 & & & & \\
\hline 2 & $\begin{array}{l}\text { Positive for Aedes } \\
\text { breeding }\end{array}$ & 15 & 2 & 5 & 7 & & & & \\
\hline 3 & $\begin{array}{l}\text { House Index(percentage of } \\
\text { house/premises positive) }\end{array}$ & 75 & 10 & 25 & 35 & & & & \\
\hline 4 & Containers searched & 40 & 30 & 20 & 25 & & & & \\
\hline 5 & Containers positive & 32 & 4 & 6 & 8 & & & & \\
\hline 6 & $\begin{array}{l}\text { Container } \\
\text { (percentage of containers } \\
\text { infested)*In examining the } \\
\text { containers, only those } \\
\text { having water have } \\
\text { counted) }\end{array}$ & 80 & 13.3 & 30 & 32 & & & & \\
\hline 7 & $\begin{array}{l}\text { Briteau Index (No. of } \\
\text { containers positive/No. of } \\
\text { houses inspected x 100) }\end{array}$ & 160 & 20 & 30 & 40 & & & & \\
\hline
\end{tabular}

Figure 4: Key breeding sites for Aedes

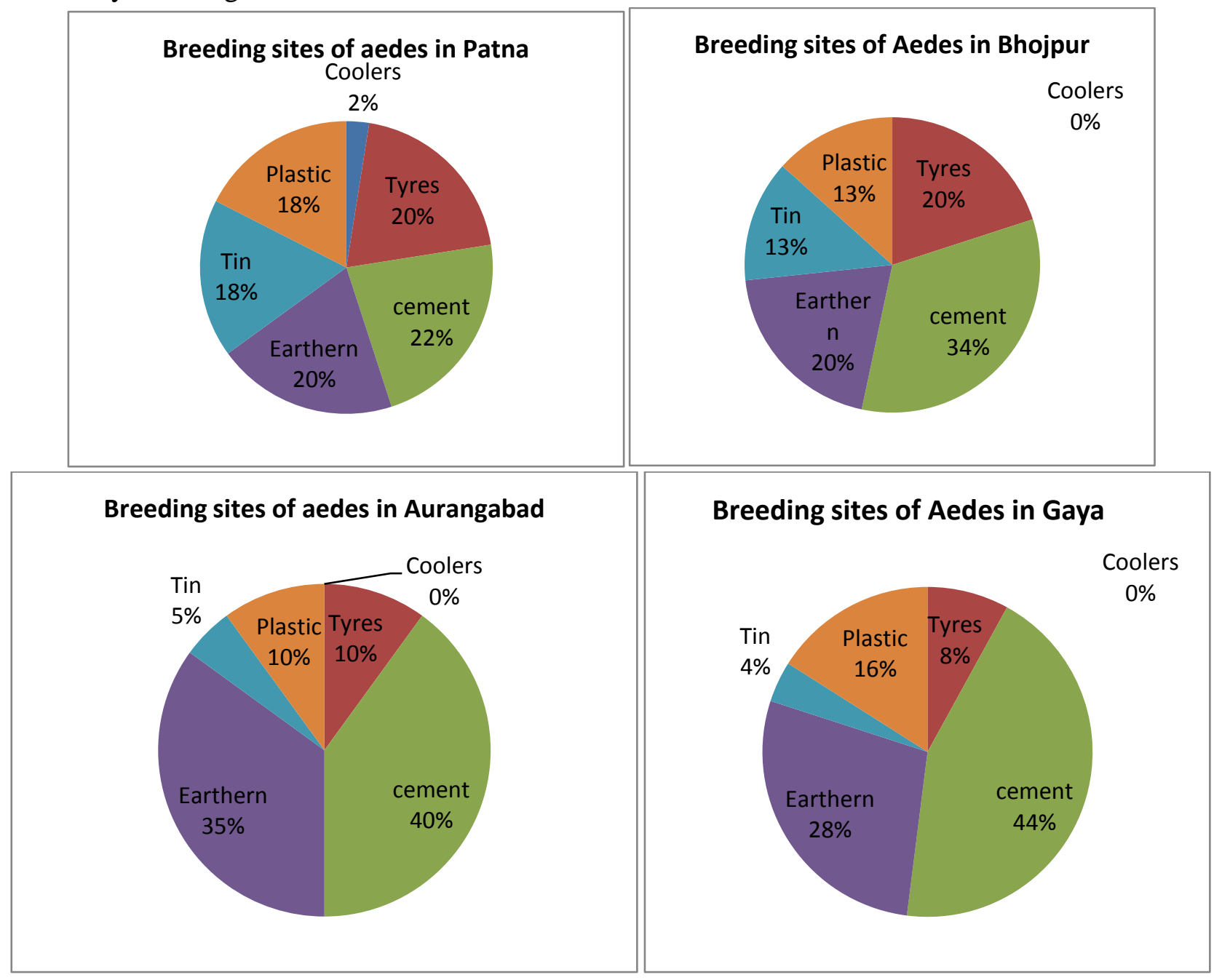


Table 7: Risk factor Analysis for dengue transmission

\begin{tabular}{|l|l|l|l|l|}
\hline Risk Factor & Patna & Bhojpur & Aurangabad & Gaya \\
\hline Potential Risk & 20 & 30 & 20 & 25 \\
\hline Wet containers in 20 houses & 1 & 1.5 & 1 & 1.25 \\
\hline Avg wet container/house & & & & \\
\hline Real Risk & 6 & 4 & 6 & 8 \\
\hline Vector infested containers & 5 & 2 & 5 & 7 \\
\hline Houses positive for breeding & 0.3 & 0.2 & 0.3 & 0.4 \\
\hline Avg positive container/house & 1.2 & 2 & 1.2 & 1.14 \\
\hline Avg positive container/ infested house & & & & \\
\hline
\end{tabular}

20 houses each in affected villages and tolas/ mohallas of the four districts was surveyed for the presence of aedine larva in several water storage containers. Out of 20 houses, 15, 2, 5 and 7 houses were positive for aedine larvae in Patna, Bhojpur, Aurangabad and Gaya district respectively. House Index (HI) was 75, 10, 25 and 35 in Patna, Bhojpur, Aurangabad and Gaya, Container Index (CI) was 80, 13, 30 and 32 Patna, Bhojpur, Aurangabad and Gaya districts and Briteau Index (BI) in was 160, 20, 30 and 40 in Patna, Bhojpur, Aurangabad and Gaya districts respectively. Based on these indices, Patna district is on higher risk of dengue transmission than other 3 districts. Risk analysis of dengue transmission in above four districts has been attached as annexure. Note: $\mathrm{HI}>10$ (critical level) and BI >20 (critical level) for transmission. Different species of mosquitoes were collected from indoor habitats at noon hours, but only aedes mosquito per man hour density has been taken into account due to its co-relation with the disease dengue. Per Man hour density of aedes was 4.1, 1, 1.7 and 1.6 in Patna, Bhojpur, Aurangabad and Gaya districts respectively. Patna district being capital of Bihar was at greater risk owing to migration of cases from the other affected States, due to construction of multi-storied buildings, densely compacted and storage of water supply in each house for longer durations owing to lack of continuous piped water supply. Maximum number of larval collection was done from Cement containers (22, 34, 40, 44\%) $>$ Earthern containers $(20,35,20,28 \%)>$ Tyres $(20$, 20, 10 and 8\%) in Patna, Bhojpur, Aurangabad and Gaya respectively.

Note: PMHD>1 (critical level) transmission. Note: during search for mosquitoes sandflies were also collected in large numbers in Gaya and Aurangabad districts (presently non-endemic and free from kala-azar)

\section{Environmental \& Sociological Observations and Results:}

These are based on standard pre-planned questionnaire \& interview with the patients \& their relatives as well as community members residing in visited villages. 
Table 8: Knowledge, Attitude and Practices of affected community

\begin{tabular}{|c|c|c|c|}
\hline \multicolumn{4}{|c|}{$\begin{array}{l}\text { Number of people interviewed }(n=50) \text { (includes combined figures from Patna, Bhojpur, Aurangabad } \\
\& \text { Gaya }\end{array}$} \\
\hline SNO & Knowledge & Yes $(\%)$ & No $(\%)$ \\
\hline 1 & Knowledge about Dengue & $35(70)$ & $15(30)$ \\
\hline 2 & $\begin{array}{l}\text { Knowledge about signs \& symptoms of } \\
\text { Dengue }\end{array}$ & $20(40)$ & $30(60)$ \\
\hline 3 & Knowledge about spread of Dengue & $15(30)$ & $35(70)$ \\
\hline 4 & Knowledge about Dengue vector & $15(30)$ & $35(70)$ \\
\hline 5 & Knowledge about prevention of Dengue & $17(34)$ & $33(66)$ \\
\hline 6 & $\begin{array}{l}\text { Knowledge about Dengue vector breeding in } \\
\text { discarded } \quad \text { water storage } \\
\text { containers/ornamental plant containers }\end{array}$ & $5(10)$ & $45(90)$ \\
\hline \multicolumn{4}{|c|}{ Attitudes \& Practice } \\
\hline 1 & Person feels mosquito bite during day time & $45(90)$ & $5(10)$ \\
\hline 2 & $\begin{array}{l}\text { Cover overhead water containers/other } \\
\text { containers }\end{array}$ & $20(40)$ & $30(60)$ \\
\hline 3 & Involved themselves in Govt efforts & $25(50)$ & $25(50)$ \\
\hline 4 & Use of repellent in day time & 0 & $50(100)$ \\
\hline 5 & Wear full cloth in day time & $20(40)$ & $30(60)$ \\
\hline 6 & $\begin{array}{l}\text { Cleaning of water coolers/other containers on } \\
\text { weekly basis }\end{array}$ & $10(20)$ & $40(80)$ \\
\hline 7 & Store water at home & $40(80)$ & 20) \\
\hline
\end{tabular}

Most of the affected population belonged to middle socio-economic strata, with most of the houses being semi-pucca/ or pucca- category. Majority of them belonged to agricultural labour community. Lots of construction activities were going on in these villages. Multi-storied buildings were also seen in these villages where water storage practices were most common. Due to no rain since last 15 days of the visit, many containers had become dried and that may pose further risk when rainfall would occur. In affected areas of Gaya district, palm and coconut shells could be found in large numbers, although they were dried up during the visit, they might serve as potential breeding sites for aedine larva once rainfall occurs. Majority of the population were illiterate and unaware of the cause of the disease. Awareness regarding disease control \& prevention was also very less. Due to lack of continuous water supply in the affected areas, water storage practices in several containers for long duration were very peculiar. Most of the affected areas were very dirty \& no proper waste management was being done.

\section{Conclusion}

Approximately 194 cases of Dengue have been reported in Bihar from $30^{\text {th }}$ June till $12^{\text {th }}$ Sep 2015. Total 34 districts were affected with the disease. District Patna was most affected followed by Bhagalpur, Bhojpur, Aurangabad and Gaya. Disease afflicted almost all age groups but the incidence was more in 21-30 age group. Males were more affected than females that may be due to long hours of work, wearing less full sleeved clothes than females increasing risk of mosquito bite etc. Vector and larval surveillance in the affected areas were positive. Per Man Hour density of Aedes aegypti was above the critical limit of transmission. High House and Briteau Index in all the four districts posed significant risk of outbreaks in the future if appropriate control measures are not put in place. Around $70 \%$ of the population was aware about the term Dengue; 
however knowledge about various aspects were lacking. Around $80 \%$ of the population stored water at home. Only $10 \%$ of the population cleaned/changed the water stored in domestic or peri-domestic containers. Community support and participation is also crucial for the prevention of future outbreaks and improving the health and well being of population in the districts. Patna district being State Capital was at greater risk than others owing to large scale migration of travelers from other affected States, construction of densely compact multi-storied buildings and storage of water in containers for longer duration owing to lack of continuous water supply. The study also showed that the disease incidence increased in monsoon and post monsoon season. Therefore, preventive measures should be initiated each year with the advent of monsoon season. In addition, vector and larval surveillance should be carried out at regular intervals to prevent the disease transmission.

\section{Recommendations}

- Strengthening of the surveillance, particularly fever along with appropriate response.

- Health Workers viz: ASHAs and ANMs should be informed to keep a close vigil on fever cases in their respective areas. If the numbers of fever cases are 5 or more in number during a period of 7 days, they should collect 5-10\% blood samples from affected population in village for serological information.

- Availability of Dengue rapid test kits at all Health Facilities to screen the preliminary cases

- Availability of Platelets should be ensured in all the Health Facilities to manage serious cases

- Health Workers should be informed to spread community awareness to check the water containing containers in respective areas and for advising to empty them at regular intervals.
- Sensitization of medical and para-medical personnel in the government as well as private sectors needs to be undertaken for appropriate and timely management of cases.

- District level coordination meeting comprising of local community leaders of affected areas and other departments like municipality and other stakeholders should be called to spread awareness regarding the disease $\&$ to prevent future outbreaks.

- Medical camps in affected areas would be beneficial to build community awareness.

- Malathion fogging in areas having greater concentration of cases or areas with higher vector density must be undertaken on a priority basis at weekly interval.

- Anti-larval measures with Temephos (Abate) in affected areas should be taken.

- Vector \& larval surveillance should be carried out throughout the year to map the vector density \& larval breeding sites. For this VBD consultant should be made well equipped.

- Awareness of Community through IEC, IPC \& BCC should be done for success of intervention methods. This should cover following aspects:

a) Cause and transmission of Dengue fever, about the vector breeding places, specifically household container breeding and biting habits, etc, symptoms of the disease, management including treatment of the cases, and community measures for prevention of breeding and to prevent man-mosquito contact.

b) Vector control measures like intensification of entomological surveillance in the area on regular basis, emptying the containers on weekly basis and scrubbiying \& drying them when not in use.

- All places adjoining the affected areas where a case of Dengue is recorded should be made alert and close vigil on all the 
fever cases should be kept for timely referral \& cases management and to prevent future outbreak.

- Availability of drugs and ELISA test kits should be made available at all key hospitals for case management and disease confirmation

- Provision of regular water supply to residential areas should be made in coordination with PHED Department to avoid long term storage of water

- Waste management should be properly planned by District Health Authorities \& Municipality.

\section{Acknowledgements}

The Authors are successful to $\mathrm{Mr}$ Jitendra Srivastava, Secretary Health-Cum-Executive Director, State Health Society for valuable support to carry out the outbreak investigation. Thanks are also due to IDSP officials of Patna, Aurangabad, Gaya and Bhojpur district for providing inputs and supports during field visit.

\section{References}

1. Gubler DJ. Dengue and dengue hemorrhagic fever: its history and resurgence as a global public health problem. In: Gubler DJ, Kuno G, editors. Dengue and dengue hemorrhagic fever. Wallingford, United Kingdom: CAB International; 1997 p. 1-22

2. Dengue haemorrhagic fever: Diagnosis, treatment, and control. Geneva: World Health Organization; 1997.

3. Monath TP. Dengue: The risk to developed and developing countries. Proc Natl Acad Sci USA 1994; 91: 2395-400.

4. International Travel and Health DENGUE [webpage on the Internet] Geneva: World Health Organization (WHO); 2013. [cited March 5, 2013]; Available from: http://www.who.int/ith/diseases/den gue/en/index.html.
5. WHO Regional Office for South-East Asia. Comprehensive Guidelines for Prevention and Control of Dengue and Dengue Haemorrhagic Fever, Revised and Expanded Edition. New Delhi: World Health Organisation South East Asia Regional Office; 2011.

6. D. J. Gubler, "Dengue and dengue hemorrhagic fever," Clinical Microbiology Reviews, vol. 11, no. 3, pp. 480-496, 1998. View at Google Scholar. View at Scopus

7. E. Gupta, L. Dar, G. Kapoor, and S. Broor, "The changing epidemiology of dengue in Delhi, India,"Virology Journal, vol. 3, article 92, 2006. View at Publisher - View at Google Scholar · View at Scopus

8. S. Balaya, S. D. Paul, L. V. D'Lima, and K. M. Pavri, "Investigations on an outbreak of dengue in Delhi in 1967," The Indian Journal of Medical Research, vol. 57, no. 4, pp. 767-774, 1969.

9. F. M. Rodrigues, M. R. Patankar, K. Banerjee et al., "Etiology of the 1965 epidemic of febrile illness in Nagpur city, Maharashtra State, India," Bulletin of the World Health Organization, vol. 46, no. 2, pp. 173-179, 1972.

10. V. S. Padbidri, C. N. Dandawate, and M. K. Goverdhan, "An investigation of the aetiology of the 1971 outbreak of febrile illness in Jaipur city, India," The Indian Journal of Medical Research, vol. 61, no. 12, pp. 1737-1743, 1973.

11. P. V. Karamchandani, "Study of 100 cases of dengue fever in Madras Penitentiary," Indian Medical Gazette, vol. 72, pp. 532-534, 1973.

12. J. K. Sarkar, S. N. Chatterjee, and S. K. Chakravarty, "Three-year study of mosquito-borne haemorrhagic fever in Calcutta," Transactions of the Royal Society of Tropical Medicine and Hygiene, vol. 61, no. 5, pp. 725-735, 1967. 
13. K. K. Mukherjee, S. K. Chakravarti, P. N. Dey, S. Dey, and M. S. Chakraborty, "Outbreak of febrile illness due to dengue virus type 3 in Calcutta during 1983," Transactions of the Royal Society of Tropical Medicine and Hygiene, vol. 81, no. 6, pp. 1008-1010, 1987.

14. B. Bandyopadhyay, I Bhattacharyya, S. Adhikary, J. Konar, N. Dawar, J.Sarkar, S. Mondal, M.S.Chauhan, N. Bhattacharya, A. Chakravarty, A.Biswas, and B. Saha "A Comprehensive Study on the 2012 Dengue Fever Outbreak in Kolkata, India" ISRN Virology, Volume 2013 (2013), Article ID 207580, Pg 1-5

15. E. Gupta, L. Dar, G. Kapoor, and S. Broor, "The changing epidemiology of dengue in Delhi, India,'Virology Journal, vol. 3, article 92, 2006.

16. Chakravarti and R. Kumaria, "Ecoepidemiological analysis of dengue infection during an outbreak of dengue fever, India," Virology Journal, vol. 2, article 32, 2005. 